\title{
SURVIVAL ANALYSIS TO DETERMINE AGE TO GIVE FIRST BIRTH IN WOMEN IN EAST JAVA USING EXTENDED COX REGRESSION
}

\author{
Santi Wulan Purnami ${ }^{1}$, Fitria Nur Aida ${ }^{2}$, Sutikno $^{3}$, Diyah Herowati ${ }^{4}$, Achmad Sjafii ${ }^{5}$, \\ Siska P. Wibisono ${ }^{6}$, Ayu Mayliawati ${ }^{7}$ \\ 1,2,3 Statistics Department, FSAD, Institut Teknologi Sepuluh Nopember (ITS), Indonesia \\ ${ }^{4,7}$ National Population and Family Planning Commission East Java Province, Indonesia \\ ${ }^{5}$ Faculty of Economics, Universitas Airlangga, 60286 Surabaya, East Java, Indonesia \\ ${ }^{6}$ Indonesian Population and Family Planning Writers Association (IPADI), East Java Province, Indonesia \\ Correspondence address: Santi Wulan Purnami \\ E-mail: santi_wp@statistika.its.ac.id
}

\begin{abstract}
The age of a woman when giving birth to her first child needs to be a concern because it is related to the safety of the mother and baby. A woman being too young or too old increases the risk of death for both the mother and baby. Every woman giving birth for the first time is likely to experience psychological disorders such as anxiety and excessive fear during labor, and even postpartum depression. Given the importance and possible extent of the consequences of women giving birth for the first time, this study intended to assess the factors that influence the age at first birth, especially amongst women of childbearing age in East Java. These factors include the age at first marriage, education, and region. The method used was the extended Cox regression model. The analysis shows that the age at first marriage and education are factors that significantly influence the age at first birth. The more mature the age at first marriage, the more mature the age at first birth. Likewise, the higher the educational status, the higher the potential for giving birth to a first child over the age of 23, especially amongst women who graduated high school and university.
\end{abstract}

Keywords: survival analysis, extended Cox, age at first birth, East Java

\begin{abstract}
ABSTRAK
Usia wanita saat melahirkan anak pertama perlu menjadi perhatian karena berkaitan dengan keselamatan ibu dan bayi. Usia yang terlalu muda atau terlalu tua meningkatkan risiko kematian pada ibu dan bayi. Setiap wanita yang pertama kali melahirkan berkemungkinan mengalami gangguan psikologis seperti kecemasan dan ketakutan berlebihan selama proses persalinan bahkan depresi pasca melahirkan. Mengingat pentingnya dan kemungkinan luasnya konsekuensi dari wanita melahirkan pertama kali, maka penelitian ini ingin mengetahui faktor yang berpengaruh terhadap usia pertama wanita melahirkan, khususnya wanita usia subur di Jawa Timur. Faktor tersebut meliputi usia kawin pertama, pendidikan dan region. Metode yang digunakan adalah analisis survival model regresi. Hasil analisis menunjukan bahwa usia kawin pertama dan pendidikan merupakan faktor Extended Cox yang berpengaruh secara signifikan terhadap usia pertama melahirkan. Semakin dewasa usia kawin pertama maka semakin dewasa usia pertama kali melahirkan. Begitu juga semakin tinggi status pendidikan maka potensi untuk melahirkan anak pertama di usia lebih dari 23 tahun cenderung akan semakin lebih besar, terutama wanita dengan pendidikan tamat SLTA dan perguruan tinggi.
\end{abstract}

Kata kunci: analisis survival, Cox extended, proportional hazard, usia pertama melahirkan

Received: March 29, 2020

Accepted: December 16, 2020

\section{INTRODUCTION}

One of the targets of the National Population and Family Planning Board of the East Java Province is to reduce the birth rate for adolescent women, especially those aged 15-19 years (ASFR 15-19 years) as stated in the Strategic Plan of the National Population and Family Planning Commission East Java Province Representative for 2015-2019
(National Population and Family Planning Commission, 2015). The main cause of birth in adolescence is premarital pregnancy, which has an impact on early marriage so that the age of first giving birth is getting younger. Of course, young women who give birth before the age of 15 years will have a higher risk of death during childbirth than women over the age of 20 years. Teenage pregnancy has risks for women and 
their offspring such as the risk of stillbirth, miscarriage, as well as abnormalities. In addition, it can cause the risk of giving birth to a baby with a lower birth weight compared to pregnancy at a productive age (Sari et al., 2017). Every woman who gives birth for the first time has a risk of experiencing psychological disorders such as anxiety or panic attacks during the delivery process, or even postpartum depression.

Women of childbearing age are women whose reproductive organs function properly between the ages of 15-49 years and have the potential to have offspring (National Population and Family Planning Commission, 2011). The birth of the first child is an important event in a woman's life. In a transition from a woman's role to being a mother with additional responsibilities, women must be prepared to put aside further education and careers. A teenager is not physically, psychologically, or financially ready to handle this (Andari and Ayuningrum, 2019). Age is a very important factor in terms of physical, psychological, and financial readiness, meaning age remains an insurmountable obstacle. As a result, it is necessary to pay more attention to the age a woman first gives birth.

Research on age at first marriage is important because it has the biggest direct effect on the decision to give birth to the first child (Kariman et al., 2016). Important factors that significantly influence the age of first marriage for women in the Trangkil District in 2014 were education, socioeconomic conditions, and perceptions of age at first marriage (Febryanti, 2015). Likewise, in West Sumatra, education and area of residence are factors that significantly influence women's decisions to marry (Sahara and Putri, 2018). The lower the level of education, the more vulnerable to early marriage (Widyawati and Pierewan, 2017). This is because the role of education is closely related to an understanding of family life. There is also a relationship between education level and knowledge of pregnant women about high-risk pregnancies (Corneles and Losu, 2015). The lower the level of knowledge, the more vulnerable women are to early marriage (Dwinanda et al., 2015). Level of health literacy also influences decision-making in the use of medication or care for pregnant and lactating women (Barnes et al., 2019). The domicile area is another variable that has a significant effect on the age a woman first gives birth (Fagbamigbe and Idemudia, 2016).

One method in survival analysis that is often used is the Cox Proportional Hazard (PH) regression. The Cox $\mathrm{PH}$ regression is a survival regression using a semiparametric approach that models the relationship between survival time with one or more predictor variables (Kleinbaum and Klein, 2012).

The results of research conducted by Fagbamigbe and Idemudia (2016) show that the time of marriage and education are the most significant factors affecting the age of first giving birth. A similar study was conducted by Chernet, Shebeshi, and Banbeta (2019) regarding the determinants of the interval for first giving birth after marriage among Ethiopian women. The results showed age, place of residence, employment status, contraceptive use, and education of women were significantly associated with the age of first giving birth (Chernet et al., 2019). Educational factors have been proven to be able to reduce the ratio of the level of danger during childbirth (Seyedtabib et al., 2019).

The Cox PH regression model produces a constant hazard ratio. The measure of this value indicates that the rate at which events occur is independent of time (Hosmer et al., 2008). If the PH assumption is not met, it is necessary to develop a Cox PH model such as the extended Cox regression model or the Cox model which involves time-dependent variables. In this study, there were two variables (age at first marriage and education) that did not meet the assumption of $\mathrm{PH}$; therefore, the model approach used was the extended Cox regression. The selection of backward elimination models was used to obtain the best model to describe the relationship between the survival time of the age of women's first birth with predictor variables correctly. Predictor variables that are thought to have an effect are age at first marriage, education, and region/domicile.

The results of this study were used to provide recommendations to the National Population and Family Planning Commission in determining policies for planning women's reproductive health programs, especially in the East Java region. Honorably, authors would like to say thank you to the National Population and Family Planning Commission in Central and the East Java for providing, supporting, and funding this research. 


\section{METHODS}

\section{Sources and data Retrieval Techniques}

This study used secondary data obtained from the 2017 Indonesian Demographic and Health Survey (IDHS) downloaded from the official Demographic and Health Surveys Program website. The data used were data from 2,756 women of childbearing age in East Java who were aged 15-49 years, had been married, and lived in the same region as when they gave birth for the first time.

The 2017 IDHS is a joint survey of several institutions, namely the Central Statistics Agency (BPS), the National Population and Family Planning Agency or Badan Kependudukan dan Keluarga Berencana Nasional (BKKBN), and the Indonesian Ministry of Health. The respondents were women who gave birth for the first time between 1968 and 30 September 2017.

The sampling design used in the 2017 IDHS was a two-stage stratified sampling. This consisted of selecting several census blocks with a systematic probability proportional to size (PPS) with the size of the number of households from the SP2010 listing. The 2017 IDHS sample covered 1,970 census blocks in both urban and rural areas. The classification of urban and rural areas is regulated in the Regulation of the Head of the Central Statistics Agency Number 37 of 2010 concerning the Classification of Urban and Rural Areas in Indonesia. A total of 47,963 households were surveyed, and 49,627 female respondents of childbearing age were successfully interviewed. There were 3,729 female respondents of childbearing age from East Java and 45,898 from other provinces. There were 3,729 women of childbearing age in East Java. This pool consisted of 2,974 women who had been married and 755 women who had never been married. In 2017, out of 2,974 female respondents, there were 2,756 female respondents of childbearing age in East Java who had been married living in the same region as when they gave birth for the first time or the current region if they had never given birth. Of these, 2,519 women gave birth between 1968 and 30 September 2017.

This study used several variables consisting of response variables and predictor variables. The response variable was survival time (T), namely age at first childbirth and censored status (d), which indicated whether the respondent experienced the event or not. The definition of an event here is the occurrence of a woman giving birth for the first time. The predictor variables studied were age at first marriage, education, and region/domicile.

Age at first marriage is the age of the respondent at their first marriage or first union obtained from the code of the month-year of marriage/first union and the code of the monthyear of birth of the respondent (ICF, 2018). Education was classified into no school, no elementary school, elementary school, junior high school, high school, and college. The noschool category was addressed to respondents who had never attended school. The category of not completing elementary school was addressed to respondents who had attended or were currently attending elementary school, while respondents who had completed elementary school were categorized as elementary school graduates. The category of not graduating from high school was addressed to respondents who had attended or were currently attending junior high school, graduated from junior high school, or had attended/were currently attending high school. Respondents who had graduated from high school were categorized as high school graduates. Respondents with an education level above high school were categorized in tertiary education. The region variable shows the type of residence where the household is located, namely urban and rural (ICF, 2018). This study used the assumption that the place of residence used was the same area as when mothers gave birth for the first time. If the woman had never given birth, the regional data showed the area where she currently lives.

Age at first giving birth is the age at which women between 15-49 years old who had been married first gave birth. The survival scheme in this study is as follows. The event under study is the event women gave birth for the first time between 1968 and 30 September 2017. The data are said to be censored if the respondent recorded had never given birth until the end of the survey period on September 30, 2017.

The variable description refers to the description of each variable code in Demographic and Health Surveys Standard Recode Manual for DHS-7. Code V212 indicates the variable age at first childbirth, code V511 indicates the variable age at first marriage, code V149 indicates the variable education, and code V025 indicates the variable region. 


\section{RESULTS}

The following characteristics of female respondents of childbearing age in East Java were described by age at first giving birth based on factors that were thought to have an effect. Then, a survival analysis was carried out starting from data exploration using the Kaplan Meier (KM) survival curve and testing the KM curve using the Log-Rank test to modeling using extended Cox regression.

\section{Data Characteristics}

Women of childbearing age in East Java who had been married give birth for the first time at the age of 21 and after 2 years of marriage on average. Meanwhile, women who had never given birth by 30th September 2017 were 29 years old on average with 7 years of marriage. This means that, on average, the majority of women of childbearing age in East Java who had been married gave birth at a young age. However, the age of women who had never given birth is varies more than the age of women who had given birth.

Table 1. Age of First Childbirth in East Java

\begin{tabular}{llc}
\hline Variables & Average & $\begin{array}{c}\text { Standard } \\
\text { Deviation }\end{array}$ \\
\hline Education & & \\
\hline No school & 18,354 & 5.149 \\
Uncompleted primary & 18,757 & 4.327 \\
school & 20,298 & 4.191 \\
Elementary school & 20.986 & 3.919 \\
Uncompleted high & 23,258 & 3.807 \\
school & 25,638 & 3.882 \\
High school graduate & & \\
College & & 4.587 \\
Region & 22,819 & 4.119 \\
\hline Urban & 20.578 & \\
Rural & & \\
\hline
\end{tabular}

Table. 1 shows the average age when first giving birth tended to increase in line with the level of last education taken. The average age at first birth of urban women was older than rural women.

\section{KM Survival Curve}

The KM survival curve is used to describe the probability of women of childbearing age in East Java who had been married to not give birth until the age of 49 years.

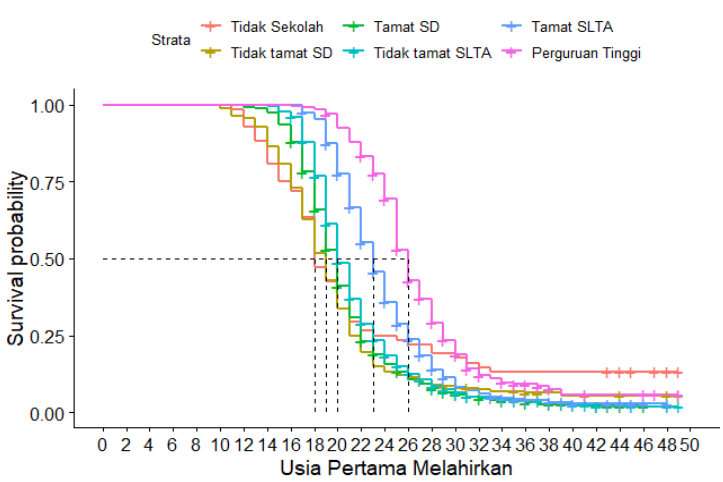

(a)

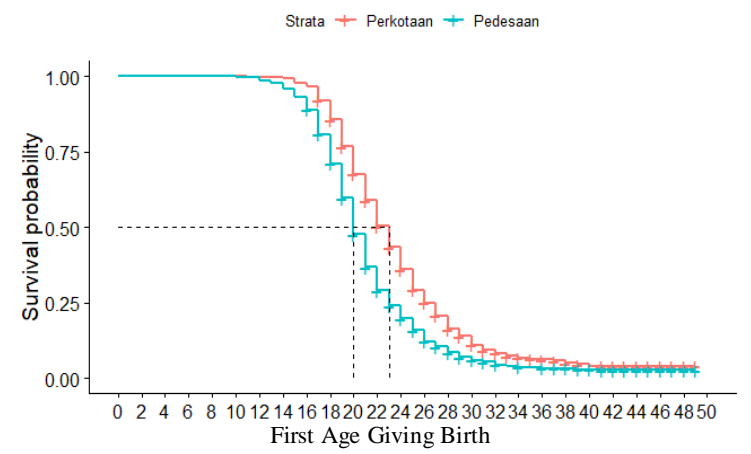

(b)

Figure 1. Kaplan Meier Curve (a) Education Factor, (b) Region Factor.

Figure 1 shows that there are differences in the age of giving birth for the first time at various levels of education. There were also differences in the age of first giving birth in rural and urban areas. The higher the education level, the higher the probability of a woman giving birth for the first time at an increasingly mature age (Figure 1. a). With a probability of about 0.5 , women who did not finish elementary school did not give birth until they were more than 18 years old, women who finished elementary school did not give birth until they were more than 19 years old, women who did not finish high school did not give birth until they were more than 20 years old, women who graduated from high school did not give birth until the age of more than 23 years, and women who had received higher education did not give birth until the age of more than 26 years.

Figure 1 (b) shows the probability of women in urban areas not giving birth is always higher than women in rural areas. This means that women who live in urban areas give birth at a more mature age than women who live in rural areas. 
Table 2. Statistical Value Calculate GOF test Based on Predictor Variables

\begin{tabular}{|c|c|c|}
\hline Variable & $\bar{\rho}$ & P-Value \\
\hline Age of First Marriage & 0.5187 & 0.0000 \\
\hline Education (1) & 0.0387 & 0.0422 \\
\hline Education (2) & 0.0774 & 0.0000 \\
\hline Education (3) & 0.0911 & 0.0000 \\
\hline Education (4) & 0.1049 & 0.0000 \\
\hline Education (5) & 0.0913 & 0.0000 \\
\hline Regions (2) & 0.0347 & 0.0685 \\
\hline
\end{tabular}

The results of the Log-Rank test of education and region variables each show the value $\chi_{(\mathrm{df} ; 0,05)}^{2}$ of 11.07 with 5 degrees of freedom and 3.84 with 1 degree of freedom then dit can be decided to reject H0. This means that there were significant differences in the KM curve between the categories of education and regions of women of childbearing age in East Java.

\section{Assumption of Proportional Hazard (PH)}

Examination of the $\mathrm{PH}$ assumption could have used the goodness of fit (GOF) test as follows. The GOF test results in Table 2 show that the variables of age at first marriage and education caused the $\mathrm{PH}$ assumption to be unfulfilled in the model because the p-value was less than the 0.05 significance level. This means that the predictor variables of age at first marriage and education depend on time. Therefore, two variables must have interacted with the time function $\mathrm{g}(\mathrm{t})$.

The time function $g(t)$ used in this study was the $\ln (\mathrm{T})$ and heavy side functions. The first modeling was modeled by including the two variables which interacted with the heavy side time function. The second modeling included one variable which interacted with the $\ln (\mathrm{T})$ function and another variable that interacted with the heavy side function.

\section{Cox Extended Regression Modeling}

Extended Cox regression modeling using a combination of heavy side time functions was done by including region variables, age at first marriage, and education variables which interacted with the heavy side function. The variable of age at first marriage in this modeling was a categorical variable derived from the division of age at first marriage into several age groups. This was done according to the results of the Residual Martingale chart with the categories of less than 15 years, 15-19 years, 20-24 years, and over 24 years. The time of change of the hazard ratio used for the variables of age at first marriage and education, respectively, was age 18 and age 23 .

The results of the LRT test produce a likelihood ratio test value $G_{h i t}^{2}$ with 17 degrees of freedom is 2253 and a value of $\chi_{(17 ; 0,05)}^{2} 27.59$. Because value $G_{h i t}^{2}$ was greater than $\chi_{(17 ; 0,05)}^{2}$, the decision to reject $\mathrm{H} 0$ was obtained, which means there were significant variables.

Extended Cox regression modeling uses a combination of time functions $\ln (\mathrm{T})$ and heavy side on region variables. Age at first marriage was used, which interacted with function $\ln (\mathrm{T})$, along with the education variable which interacted with the heavy side function. The time of change of the hazard ratio used for the education variable was age 23 .

Extended Cox regression modeling using a combination of time functions $\ln (\mathrm{T})$ and heavy side produced a likelihood ratio test value $G_{h i t}^{2}$ by 2,810 with degrees of freedom 13 and the value of $\chi_{(13 ; 0,05)}^{2}$ of 22.36. H0 was rejected, which meant that there were variables in the model that significantly affect the age of first giving birth.

Table 3 provides the results of partial parameter significance testing in modeling using a combination of heavy side time functions. The variables of first married age group, education, and region had a significant effect on the model. The modeling that used a combination of time functions $\operatorname{Ln}(\mathrm{T})$ and Heaviside gave the result that the region variable had no significant effect on the model. The first married age and education variables had a significant effect on the model. 
Table 3. Parameter Estimation Results of the Extended Cox Model

\begin{tabular}{|c|c|c|}
\hline Variables & Parameter Estimation & P-value \\
\hline \multicolumn{3}{|l|}{ Heaviside Time Function Combination } \\
\hline Regions (2) & 0.0951 & $\mathbf{0 . 0 3 5 2}$ \\
\hline Age Group at First Marriage $(1)^{*} g_{11}(t)$ & -1.6360 & 0.0000 \\
\hline Age Group at First Marriage $(2)^{*} g_{11}(t)$ & -5.8984 & 0.0000 \\
\hline Age Group at First Marriage $(3)^{*} g_{11}(t)$ & -6.4639 & 0.0000 \\
\hline Education $(1)^{*} g_{12}(t)$ & 0.3748 & 0.0470 \\
\hline Education $(2)^{*} g_{12}(t)$ & 0.1637 & 0.3489 \\
\hline Education $(3)^{*} g_{12}(t)$ & 0.1425 & 0.4172 \\
\hline Education $(4)^{*} g_{12}(t)$ & -0.1073 & 0.5459 \\
\hline Education $(5)^{*} g_{12}(t)$ & -0.8371 & 0.0000 \\
\hline Age Group at First Marriage $(1)^{*} g_{21}(t)$ & 0.8893 & 0.0003 \\
\hline Age Group at First Marriage $(2)^{*} g_{21}(t)$ & 0.0010 & 0.9968 \\
\hline Age Group at First Marriage $(3)^{*} g_{21}(t)$ & -1.1656 & 0.0000 \\
\hline Education $(1)^{*} g_{22}(t)$ & 0.7739 & 0.1123 \\
\hline Education $(2)^{*} g_{22}(t)$ & 1.2408 & 0.0031 \\
\hline Education $(3) * g_{22}(t)$ & 1.4968 & 0.0004 \\
\hline Education $(4) * g_{22}(t)$ & 2.1067 & 0.0000 \\
\hline Education $(5)^{*} g_{22}(t)$ & 2.0638 & 0.0000 \\
\hline \multicolumn{3}{|c|}{ Combination of $\operatorname{Ln}(T)$ and Heaviside Time Functions } \\
\hline Regions (2) & -0.0291 & 0.5861 \\
\hline Age of First Marriage & -2.5223 & 0.0000 \\
\hline Education $(1)^{*} g_{12}(t)$ & 0.4902 & 0.1158 \\
\hline Education $(2)^{*} g_{12}(t)$ & 0.7225 & 0.0084 \\
\hline Education $(3)^{*} g_{12}(t)$ & 0.7627 & 0.0075 \\
\hline Education $(4)^{*} g_{12}(t)$ & 0.7619 & 0.0069 \\
\hline Education $(5)^{*} g_{12}(t)$ & 0.1562 & 0.6050 \\
\hline Age of First Marriage* $\ln (\mathrm{T})$ & 0.7327 & 0.0000 \\
\hline Education $(1)^{*} g_{22}(t)$ & 0.7294 & 0.1107 \\
\hline Education $(2)^{*} g_{22}(t)$ & 1.4525 & 0.0001 \\
\hline Education $(3)^{*} g_{22}(t)$ & 1.6436 & 0.0000 \\
\hline Education $(4)^{*} g_{22}(t)$ & 1.9775 & 0.0000 \\
\hline Education $(5)^{*} g_{22}(t)$ & 1.9200 & 0.0000 \\
\hline
\end{tabular}

Information: P-values in bold are significant

Selection of The Best Time Function Combination Based on AICc Criteria

The modeling by including the combination of the time functions $\operatorname{Ln}(\mathrm{T})$ and Heaviside produced an AICc value of 33,093.59 while the modeling by including the combination of the Heaviside time functions produced an AICc value of 33660.16. The second model, which is a combination of time functions $\operatorname{Ln}(\mathrm{T})$ and heaviside, is the best model (because the resulting AICc value is smaller) that will be used in the next modeling.

\section{Selection of The Best Model Using Backward Elimination}

Backward elimination was carried out on modeling that used a combination of time functions $\operatorname{Ln}(\mathrm{T})$ and Heaviside by eliminating the least significant variables gradually. 
The best extended Cox model consisting of variables that significantly affect the age of first delivery can be written as follows.

$$
\begin{aligned}
& \hat{h}(t, \mathbf{x})= \\
& \hat{h}_{0}(t) \exp \left[-2,51828 \text { UsiaKawinPertama }+0,48998 \text { Pendidikan }(1) * g_{12}(t)\right. \\
& \quad+0,72303 \text { Pendidikan }(2) * g_{12}(t)+0,76627 \text { Pendidikan }(3) * g_{12}(t) \\
& \quad+0,76996 \text { Pendidikan }(4) * g_{12}(t)+0,16545 \text { Pendidikan }(5) * g_{12}(t) \\
& \quad+0,73160 \text { UsiaKawinPertama } * \ln (t)+0,72768 \text { Pendidikan }(1) * g_{22}(t) \\
& \quad+1,45259 \text { Pendidikan }(2) * g_{22}(t)+1,65134 \text { Pendidikan }(3) * g_{22}(t) \\
& \left.\quad+1,98906 \text { Pendidikan }(4) * g_{22}(t)+1,93376 \text { Pendidikan }(5) * g_{22}(t)\right]
\end{aligned}
$$

The likelihood ratio test value $G_{h i t}^{2}$ obtained was 2,810 with degrees of freedom as large as 12 and the value of $\chi_{(12 ; 0,05)}^{2} 21.03$. It rejected $\mathrm{H} 0$, which means that there was at least one variable in the model that significantly affected the age at first giving birth.

The likelihood ratio test value $G_{h i t}^{2}$ obtained was 2,810 with degrees of freedom as large as 12 band the value of $\chi_{(12 ; 0,05)}^{2} 21.03$. It rejected $\mathrm{H} 0$, which means that there was at least one variable in the model that significantly affected the age at first giving birth.

\section{Hazard Ratio Value}

The value of the hazard ratio of women with age at first marriage was not constant depending on time. The hazard ratio value for the education variable is illustrated in Figure 2.

Overall, the higher the educational status, the higher the potential for giving birth to their first child at the age of more than 23 years. This is especially true for women who have graduated from high school and college. The higher the education level of women, the more mature the age at first giving birth or the more delay in giving birth to their first child.

\section{DISCUSSION}

The best model produced from this research was the Cox extended regression which used a combination of $\operatorname{Ln}(\mathrm{T})$ and heavy side functions. The results of this model concluded that age at first marriage and education were the factors that had a significant effect on age at first giving birth. These results are in line with similar studies conducted in Ethiopia (Chernet et al. 2019) and in Nigeria (Fagbamigbe and

\begin{tabular}{|c|c|c|}
\hline Variable & Parameter Estimation & P-value \\
\hline Age of First Marriage & $-2,51828$ & 0.00000 \\
\hline Education $(1)^{*} g_{12}(t)$ & 0.48998 & 0.11589 \\
\hline Education $(2)^{*} g_{12}(t)$ & 0.72303 & 0.00823 \\
\hline Education $(3)^{*} g_{12}(t)$ & 0.76627 & 0.00705 \\
\hline Education $(4)^{*} g_{12}(t)$ & 0.76996 & 0.00596 \\
\hline Education $(5)^{*} g_{12}(t)$ & 0.16545 & 0.58125 \\
\hline Age of First Marriage* $\ln (\mathrm{T})$ & 0.73160 & 0.00000 \\
\hline Education $(1)^{*} g_{22}(t)$ & 0.72768 & 0.11151 \\
\hline Education $(2)^{*} g_{22}(t)$ & 1.45259 & 0.00010 \\
\hline Education $(3)^{*} g_{22}(t)$ & 1.65134 & 0.00001 \\
\hline Education $(4)^{*} g_{22}(t)$ & 1.98906 & 0.00000 \\
\hline Education $(5)^{*} g_{22}(t)$ & 1.93376 & 0.00000 \\
\hline
\end{tabular}
Idemudia, 2016). The study concluded that the younger a woman married, the earlier the age of first giving birth. In addition, women with higher education tended to be more mature when giving birth for the first time.

Table 4. The Best Extended Cox Model Parameter Estimation Results

Information: P-values in bold indicate significant variables. 


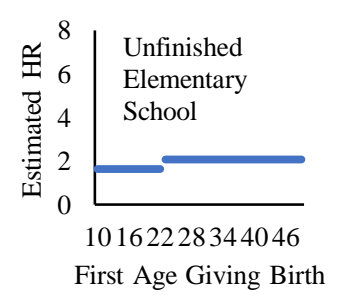

(a)

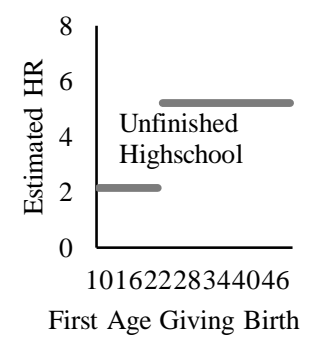

(c)

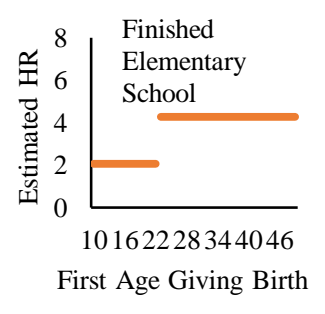

(b)

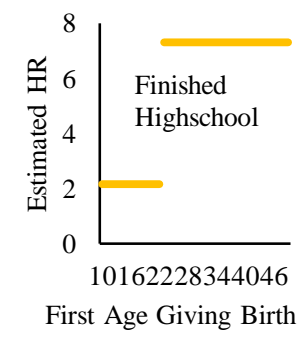

(d)

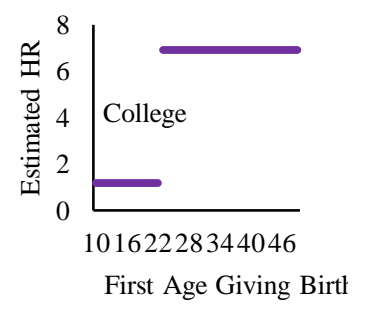

(e)

Figure 2. Hazard Ratio Value of Educational Factors.

In more detail, the results of this study are described in Figure 2. The higher a woman's education, the greater the likelihood of giving birth at the age of more than 23 years, especially when they have received higher education (Figure 2. e). The probability of giving birth for the first time from every level of education of women increases at the age of more than 23 years compared to those aged less than 23 years. This increase in probability varies by category of women's educational status and a sharp increase occurs in the education status of high school and college graduates.

Delaying the first birth as a strategy to improve maternal health can be achieved if women are empowered from an early age with quality education; therefore, stakeholders should pay adequate attention to educating girls. Health education and promotion of the need to delay childbearing should be intensified, especially for women with low education.

\section{CONCLUSIONS AND SUGGESTIONS}

\section{Conclusion}

This study wanted to determine the factors that influence the first age of women giving birth, especially women of childbearing age in East Java. These factors include age at first marriage, education, and region. The best survival model used was the extended Cox model using a combination of $\operatorname{Ln}(\mathrm{T})$ and Heaviside functions.

The results obtained indicate that the variables of age at first marriage and education significantly affect the age of first giving birth. The more mature the age at first marriage, the more mature the age at first giving birth, followed by a greater potential for giving birth for the first time. The potential for giving birth for the first time at the age of more than 23 years from each category of women's educational status has increased compared to those aged less than 23 years, especially among high school and college graduates. The higher the education level of women, the more mature their age when first giving birth or the more delay in giving birth to their first child.

\section{Suggestion}

Suggestions for further research are to use other methods such as the stratified Cox regression and identify predictor variables that are relevant to the age of first delivery. Recommendations that can be put forward as consideration for the East Java Province BKKBN program, namely the Marriage Age Maturation Program is still very important, especially for the East Java Province. Massive socialization related to early planning education and reproductive health education for adolescents should be done through the GenRe (Generation Planning) program. The education of women of childbearing age needs to be encouraged, especially among women lacking higher education.

\section{REFERENCES}

Andari, F. N., and Ayuningrum, R. (2019). Pengalaman Persalinan Pertama Dengan Riwayat Menikah Dini di Kelurahan Pagar Dewa Kota Bengkulu. Jurnal Keperawatan Sriwijaya, 6(2), 26-33. 
Barnes, L. A. J., Barclay, L., McCaffery, K., and Aslani, P. (2019). Factors Influencing Women's Decision-Making Regarding Complementary Medicine Product Use In Pregnancy and Lactation. BMC Pregnancy and Childbirth, 19(280), 114.

Chernet, A. G., Shebeshi, D. S., and Banbeta, A. (2019). Determinant of Time-To-First Birth Interval after Marriage among Ethiopian Women. BMC Woman's Health, 19(157), 1-6.

Corneles, S. M., and Losu, F. N. (2015). Hubungan Tingkat Pendidikan dengan Pengetahuan Ibu Hamil Tentang Kehamilan Risiko Tinggi. Jurnal Ilmiah Bidan, 3(2), 51-55.

Dwinanda, A. R., Wijayanti, A. C., and Werdani, K. E. (2015). Hubungan Antara Pendidikan Ibu dan Pengetahuan Responden dengan Pernikahan Usia Dini. Jurnal Kesehatan Masyarakat Andalas, 10(1), 76-81.

Fagbamigbe, A. F., and Idemudia, E. S. (2016). Survival Analysis and Prognostic Factors of Timing of First Childbirth among Women in Nigeria. $B M C$ Pregnancy and Childbirth, 16, 16(102), $1-12$.

Febryanti, L. (2015). Kontribusi Faktor Pendidikan Terhadap Usia Perkawinan Pertama Wanita di Kecamatan Trangkil Kabupaten Pati. Jurnal Geografi, 12(1), 39-51.

Hosmer, D. W., Lameshow, S., and May, S. (2008). Applied Survival Analysis: Regression Modelling of Time Event Data. John Willey.

ICF. (2018). Demographic and Health Surveys Standard Recode Manual for DHS7. ICF.

Kariman, N., Amerian, M., Jannati, P., Salmani, F., and Hamzekhani, M. (2016). A Path
Analysis of Factors Influencing the First Childbearing Decision-Making In Women In Shahroud In 2014. Glob J Health Sci., 8(10), 24-33.

Kleinbaum, D. G., and Klein, M. (2012). Statistics for Biology and Health Survival Analysis: Learning Text Third Edition. Springer.

National Population and Family Planning Commission. (2011). Kamus Istilah Kependudukan dan Keluarga Berencana.

National Population and Family Planning Commission. (2015). Rencana Strategis Perwakilan Badan Kependudukan Dan Keluarga Berencana Nasional Provinsi Jawa Timur Tahun 2015-2019.

Sahara, N., and Putri, D. Z. (2018). FaktorFaktor yang Mempengaruhi Keputusan Wanita Menikah di Sumatera Barat. EcoGen, 1(3), 640-647.

Sari, D. P., Setianingsih, and Rahayu, W. (2017). Pengaruh Kehamilan Remaja Terhadap Bayi Berat Badan Lahir Rendah. Jurnal SMART Keperawatan Sekolah Tinggi Ilmu Kesehatan (STIKes) Karya Husada, 4(2), 56.

Seyedtabib, M., Moghimbeigi, A., Mahmoudi, M., Majdzadeh, R., and Mahjub, $\mathrm{H}$. (2019). Pattern and Determinant Factors of Birth Intervals among Iranian Women: A Semi-Parametric Multilevel Survival Model. Journal of Biosocial Science, 52(4), 1.

Widyawati, E., and Pierewan, A. C. (2017). Determinan Pernikahan Usia Dini di Indonesia. Jurnal Ilmu-Ilmu Sosial, 14(4), 68. 